\title{
Study on Callus Induction System of 4 Genotype of Napiergrass (Pennisetum purpureum )
}

\author{
Nafiatul Umami ${ }^{1}$, Ryo Akashi ${ }^{2}$, Takahiro Gondo ${ }^{2}$, Genki Ishigaki ${ }^{2}$, Hidenori Tanaka ${ }^{2}$ \\ ${ }^{1}$ Faculty of Animal Science, Universitas Gadjah Mada, JI. Fauna No 3 Yogyakarta \\ ${ }^{2}$ Faculty of Agriculture University of Miyazaki, Japan \\ Corresponding author email: nafiatul.umami@ugm.ac.id
}

\begin{abstract}
The aim of this study was to produce callus induction potential of 4 napiergrass (Pennisetum purpureum) genotypes (Dwarf Late, Hybrid, Merkeron and Wrukwona). Callus was induced from shoot apices of shoot tillers on MS media containing 2.4-D and BAP. On the MS medium containing $2 \mathrm{mg} \mathrm{L}^{-1} 2,4-\mathrm{D}$ and 0.5 $\mathrm{mg} \mathrm{L}^{-1} \mathrm{BAP}$ all genotypes could produce embryogenic calli, with different rate of growth. The best genotype for producing embryogenic calli was dwarf napiergrass in 60 day culture. These genotypes would be useful for tissue cultured based research and for napiergrass improvement program, particularly in genetic transformation. Culturing shoot apices on MS medium containing $2 \mathrm{mgL}^{-1} 2,4-\mathrm{D}$ and $0.5 \mathrm{mgL}^{-1}$ BAP was more suitable than on MS medium containing $0.5 \mathrm{mgL}^{-1} 2,4-\mathrm{D}$. In the subculture with similar medium composition, proliferation occured poorly on dwarf napiergrass, whereas none happened on the three other genotypes. On the hormon-free medium, all genotypes germinated in different rates. This research pointed out that dwarf napiergrass gave the best response toward induction medium. However, its proliferation and regeneration needed to be optimized in order to obtain more obvious data. This genotype would be useful for tissue culture based research and for napiergrass improvement program, particularly in genetic transformation.
\end{abstract}

Key words: Tissue culture, callus, Pennisetum purpureum, forages, improvement .

Abstrak. Tujuan dari penelitian ini adalah untuk mengetahui potensi induksi kalus dari empat genotip napiergrass (rumput gajah) (Dwarf Late, Hybrid, Merkeron dan Wrukwona). Kalus diinduksi dari apex atau tunas pucuk pada media MS yang mengandung 2,4-D dan BAP. Penelitian menunjukkan pada media MS yang mengandung $2 \mathrm{mg} \mathrm{L}^{-1}$ 2,4-D dan 0,5 $\mathrm{mg} \mathrm{L}^{-1}$ BAP semua genotip bisa menghasilkan kalus embriogenik, dengan tingkat pertumbuhan yang berbeda. Genotip terbaik untuk memproduksi kalus embriogenik adalah dwarf late napiergrass dalam waktu induksi 60 hari. Hasil ini bermanfaat untuk program peningkatan napiergrass khususnya dalam proses transformasi genetik. Kultur apex pucuk pada media MS yang mengandung $2 \mathrm{mgL}^{-1}$ 2,4-D dan $0,5 \mathrm{mgL}^{-1} \mathrm{BAP}$ itu lebih baik dari pada media MS yang mengandung $0,5 \mathrm{mgL}^{-1}$ 2,4-D. Dalam subkultur dengan menggunakan komposisi media yang sama, proliferasi terbentuk pada dwarf late napiergrass, sedangkan tidak terjadi proliferasi pada tiga genotipe lainnya. Pada media bebas hormon, semua genotip berkecambah dengan kondisi yang berbeda. Penelitian ini menunjukkan bahwa dwarf late napiergrass memberikan respon terbaik terhadap media induksi. Namun, proliferasi dan regenerasi perlu dioptimalkan untuk mendapatkan data yang lebih jelas. Penelitian genotipe ini berguna untuk penelitian berbasis kultur jaringan dan untuk program peningkatan napiergrass, khususnya dalam transformasi genetik.

Kata kunci: kultur jaringan, kalus, rumput gajah, hijauan, perbaikan kualitas

\section{Introduction}

Plant tissue culture methods of tropical grass; bermuda grass (Chudury et al., 2000), Rhodes grass (Gondo et al., 2007), Ruzi grass (Ishigaki et al., 2009), Bahia grass (Paspalum notatum flugge) ( Akashi et al., 1993), Panicum virgatum (Burris et al. 2009), Dallis grass (Paspalum dilatatum poir) (Akashi and Adachi 1992), Vetiveria (Vetiveria zizoinoides) (Prasertsongskun 2003), Brachiaria brizantha
(Cabral et al., 2011) and rhodes grass (Cenchrus ciliaris) (Colomba et al., 2006), have been reported. A lot of research has been reported on Pennisetum purpureum Schum. Vasil (1981) reported about regenerated planted from somatic embryogenesis from leaf tissue and anther of Pennisetum purpureum cv Schum. Chudhury et al. (2000) studied about regenerated plant from somatic embryogenesis from inflorescence segment of bermuda grass 
and (Ochatt et al., 2001) studied about regenerated plant from protoplast of Lathyrus sativus L. Attemp to culture Pennisetum purpureum cv Mott with somatic embryo formation and multiple-shoot clumps for shoot apical meristem of Pennisetum purpureum cV Mott were not studied. Vasil and Vasil (1984) suggested that young meristematic inflorescence of gramineae were most useful for in vitro culture. While the explants for gramineae research was young inflorescence leaf tissue and mature cariopsis (Marousky and West, 1990) have been use to induce somatic embryogenesis.

Callus induction is one of the substantial steps for selecting the suitablility of genotype for tissue culture-based research and for plant improvement program, particularly for genetic transformation. Another gramineae study, in rice, different callus type, can be induced (Virasada et al., 2002). Type 1 callus is white and cream colored compact organized callus, type II is yellow organized callus, type III is yellow or brown unorganized callus, and the type IV is highly unorganized white, yellow or brown callus. Type 1 and Type II calluses are embryogenic and can be induced from tissues of various organs such as immatures seeds, immature embryo and roots. The type III callus is dark and necrotic. In general, immature embryos and meristematic tissues, having undifferentiated cells, are suitable for callus induction and plant regeneration than mature tissues (Morrish et al., 1987), However, such explants are available only in a resticted period of the growth cycle in the plant, and to obtain such explants all year round, we have to grow the plants in greenhouse. However, embryos of mature seeds are available throughout the year, and are more suitable for grasses callus culture. The embryogenic callus induced by culture of mature seeds are effectively used for genetic transformation by particle bombardment (Gondo et al., 2007; Ishigaki et al., 2009). The aseptic culture of root explants is also useful since it is relatively easy to provide in any season.

In the in vitro culture of grasses, a significant difference in callus induction has been found among the different genotype of bahia grass (Akashi et al., 1993). Pensacola had the best response in embryogenic callus formation and regeneration. Different genotype have different respon on culture medium, which may in some genotype will be limit the succes in the transformation process.

Callus induction as well as regeneration potential is affected not only by genotype and the type of explant, but also by the composition of the culture medium including plant growth regulators, and by the culture conditions. However, in particular, genotype and type of explant are important factors for the successfull embryogenic callus induction and regeneration of plant. In this study, in the pre experiment, genotypic differences among 4 napiergrass genotypes in callus induction potential was examined, combined with two types of explants (shoot tiller and axillary buds) using two diffrent type of combination hormone in MS media (Vasil and Haydu 1981) and (Vasil et al., 1982).

The objective of the present study was to identify callus potential of 4 genotypes of napiergrass. The genotypes identified to have a good induction potential could then be utilized in tissue culture based studies directed for the coming genetic transformation studies with the valuable method.

\section{Materials and method}

Four genotypes of napiergrass, Dwarf late, Hybrid, Merkeron, and Wrukwona were used in the experiment since this genotype has been widely used as forage and vegetative grasses. The first, shoot tillers and axilary buds were used as explant in the culture induction.

\section{Explants sterilization}

Shoot-tillers of four varieties of napier grass (Pennisetum purpureum Schum) used for explants were collected from the Field. The 
shoot-tillers were washed with running tap water to remove sand and dust particles. They were sterilized by immersing them in $70 \%(\mathrm{v} / \mathrm{v})$ ethanol for 2 minutes, followed by immersion in a $2 \%(\mathrm{v} / \mathrm{v})$ sodium hypochloride solution. The solution containing the shoot-tips was agitated for 15 minutes, followed by three washes with sterilized water for 2 minutes.

\section{Embryogenic calli formation}

Shoot apices were excised from shoot-tiller and they were cultured on MS Murashige Skoog (MS) media (Murashige and Skoog 1962) containing $3 \%$ sucrose, $0.3 \%$ phytagel and $0.1 \%$ (v/v) preservative for plant tissue culture media supplemented with various concentration of hormon. These induction media containing 2,4dichlorophenoxyacetic acid (2,4-D: 0.0, 0.01, 0.1 , and $0.5 \mathrm{mg} \mathrm{L}^{-1}$ ) and 6-benzylaminopurine (BAP: 0.0 and $2.0 \mathrm{mg} \mathrm{L}^{-1}$ ). The induction frequency of multiple-shoot clumps was calculated. In order to proliferate, multipleshoot clumps were transferred to MS induction media (2.0 $\mathrm{mg} \mathrm{L}^{-1} \mathrm{BAP}$ and $0.1 \mathrm{mg} \mathrm{L}^{-1} 2,4-\mathrm{D}$ ) supplemented with several concentration of $\mathrm{CuSO}_{4}(0,5$ and $50 \mu \mathrm{M})$. The percentage of clump proliferation was calculated after 14 days culture.

\section{Plant regeneration conditions}

For plant regeneration, multiple-shoot clumps were transferred into MS basal medium containing $3 \%$ sucrose and $0.3 \%$ phytagel supplemented with 0.0 and $2.0 \mathrm{mg} \mathrm{L}^{-1}$ BAP in combination with $0.0,0.01,0.1$ and $0.5 \mathrm{mg} \mathrm{L}^{-1}$ $\alpha$-naphthalene acetic acid (NAA). After 14 days culture, the plant regeneration percentage was calculated. Elongated shoots were transferred to fresh half-strength MS medium to induce root development. All media were adjusted to $\mathrm{pH}$ 5.6-5.8 prior to being autoclaved at $121^{\circ} \mathrm{C}$ for 15 minutes. The cultures were incubated under fluorescent lights of 3500 lux for 16 hours at $27^{\circ} \mathrm{C}$.

The in vitro regenerants were taken out from the tubes carefully and washed in water to remove nutrient and agar. Afterwards, they were transferred to soil directly in nursery pot for nursery, covered with agro-net in the greenhouse.

\section{Statistical analysis}

The data were analyzed by analysis of variance (ANOVA) and Tukey's test using SPSS 10 software .

\section{Results and Discussion}

In the pre experiment, dwarf napiergrass genotype was cultured in callus induction. The explants were sterilized by sterilizing solution and cultured onto hormon-combined medium. After 14 days-culturing, they were moved to a new medium. The improvement was observed and the data was taken on the second week. Axillary buds was not good explant because during induction, $90 \%$ of the culture was contaminated, whereas only $10 \%$ of explants could survive in the culture. Meanwhile, of the explants using shoot tillers, almost $90 \%$ could survive and grow without contamination. Based on this result, we used shoot tillers as explant in the callus induction for the continuing experiment.

All genotypes induced callus, but callus induction ability varied from each genotype. Total number of genotype with callus is showed in Table 1. The highest culture is $98.3 \%$ in which callus can be formed from explants, and $26.7 \%$ is embryogenic calli. Only in the MS medium containing $2 \mathrm{mg} \mathrm{L}^{-1} 2,4-\mathrm{D}$ and $0.5 \mathrm{mg} \mathrm{L}^{-1} \mathrm{BAP}$, calli could be produced.

Figure 1 shows the induced callus of some genotypes. Hybrid and Wrukwona had poor callus induction ability. On day 30 of culture, as shown in Figure 1, all explants did not show complete embryogenic calli induction and embryogenic calli number was very small. Only after 45 - 60 days, embryogenic calli appeared greater in quantity as shown in Figure 1.

In this research, pra experiment used shoot apices and axillary buds as explant. The result showed culture condition resulted from axillary 
buds was not a good explant because after being treated in various sterilization concentration and method, the contamination rate of the culture medium remained high (90\%). Therefore, in the following research we used tiller as apical meristem source for callus induction. There were two types of induction medium employed referring to the former research, in which the researchers used different explant, mainly from young leaf. In this research, we used explant from shoot apex and shoot buds that contained apical meristem was the best for embryogenic calli induction.

Table 1 shows that all media can produce callus but on the medium consisting of $\mathrm{MS}$ medium containing $1 \mathrm{mg} \mathrm{L}^{-1} 2,4-\mathrm{D}, 0.5 \mathrm{mg} \mathrm{L}^{-1}$ BAP and $1 \mathrm{mg} \mathrm{L}^{-1} \mathrm{NAA}$, there are many soft callus formed after 60 days observation and embryogenic callus appear together with soft calli. On MS medium containing $2 \mathrm{mgL}^{-1}$ 2,4-D and $0.5 \mathrm{mgL}^{-1}$ BAP $80 \%$ explants can form wellgrowing embryogenic calli of dwarf genotype after $60^{\text {th }}$ days of observation.

Figure 2 shows that different genotype responds differently related to callus growth. Embryogenic calli appear on all genotypes.

In the next step of research, embryogenic calli resulted from 4 different genotypes were proliferated by subculturing on the similar medium with medium for inductiom. The result is shown in Table 2.

During this proliferation research, we used the same medium as the induction medium. Subculturing was conducted one in every two weeks by transferring callus to the fresh medium. The proliferation capacity of each medium was different. On the culture of dwarf napiergrass, compact callus remained showing its proliferation rate on MS medium containing $2 \mathrm{mgL}^{-1} \quad 2,4-\mathrm{D}$ and $0.5 \mathrm{mgL}^{-1}$ BAP. The result after two week observation is presented in Figure 3. Figure 3 shows that on the second week of observation callus remains appearing compactly without the presence of necrosis or browning and sodt callus formation on the medium.

On the culture medium for callus that was derived from hybrid variety, embryogenic calli on D2B0.5 medium did not proliferate but it directly germinate by forming shoots on the culture medium. It was less favorable because we needed much more calli for transformation.

In the culture of merkeron genotype, on D2B0.5 media, some calli formed shoots and roots simultaneously on the culture medium. It is shown in Figure 3. The similar condition with the culture of hybrid was seen in the culture of merkeron on the same medium.

Table 1. Formation of embryogenic calli derived from shoot apices in tiller of 4 genotypes napiergrass

\begin{tabular}{|c|c|c|c|c|c|c|}
\hline Medium & Genotype & $\begin{array}{c}\text { No. of } \\
\text { inoculated } \\
\text { shoot } \\
\text { apices }\end{array}$ & $\begin{array}{l}\text { No. of calli } \\
\text { formed (\%) }\end{array}$ & $\begin{array}{c}\text { No. of } \\
\text { embryogenic } \\
\text { calli formed (30 } \\
\text { days) (\%) }\end{array}$ & $\begin{array}{c}\text { No. of } \\
\text { embryogenic } \\
\text { calli formed (60 } \\
\text { days) (\%) }\end{array}$ & $\begin{array}{l}\text { Embryo } \\
\text { genic } \\
\text { calli } \\
\text { growth }\end{array}$ \\
\hline \multicolumn{7}{|c|}{ MS-D2B0.5 } \\
\hline & Dwarf & 60 & $59.0 \pm 1.0(98.3)$ & $15.3 \pm 0.5(26.7)^{a}$ & $48 \pm 1.0(80.0)^{\mathrm{ac}}$ & $* * * *$ \\
\hline & Hybrid & 60 & $55 \pm 1.0(93.3)$ & $13 \pm 1.0(21.7)^{\mathrm{a}}$ & $22 \pm 1.0(36.6)^{\mathrm{cd}}$ & $* * * *$ \\
\hline & Merkeron & 60 & $56.3 \pm 1.0(95.0)$ & $14 \pm 1.0(23.3)^{\mathrm{a}}$ & $49 \pm 1.0(81.7)^{\mathrm{bd}}$ & $* * * *$ \\
\hline & Wrukwona & 60 & $53.6 \pm 1.5(90.0)$ & $2 \pm 1.0(3.3)^{b}$ & $13 \pm 1.0(21.7)^{\mathrm{cd}}$ & $* * *$ \\
\hline \multicolumn{7}{|c|}{ MS-DB0.5N } \\
\hline & Dwarf & 60 & $20 \pm 1.0(66.6)^{b}$ & $0^{\text {ns }}$ & $4 \pm 1.7(6.6)^{b}$ & $\begin{array}{l}\text { Soft } \\
\text { callus }\end{array}$ \\
\hline & Hybrid & 60 & $16.6 \pm 1.5(53.3)^{\mathrm{bd}}$ & 0 & $2 \pm 1.0(3.3)^{b}$ & $\begin{array}{l}\text { Soft } \\
\text { callus }\end{array}$ \\
\hline & Merkeron & 60 & $25 \pm 1.0(83.3)^{a}$ & 0 & $5 \pm 1.0(8.3)^{a}$ & $\begin{array}{l}\text { Soft } \\
\text { callus }\end{array}$ \\
\hline & Wrukwona & 60 & $15 \pm 3.4(50.0)^{d}$ & 0 & $7 \pm 1.0(11.6)^{a}$ & $\begin{array}{l}\text { Soft } \\
\text { callus }\end{array}$ \\
\hline
\end{tabular}



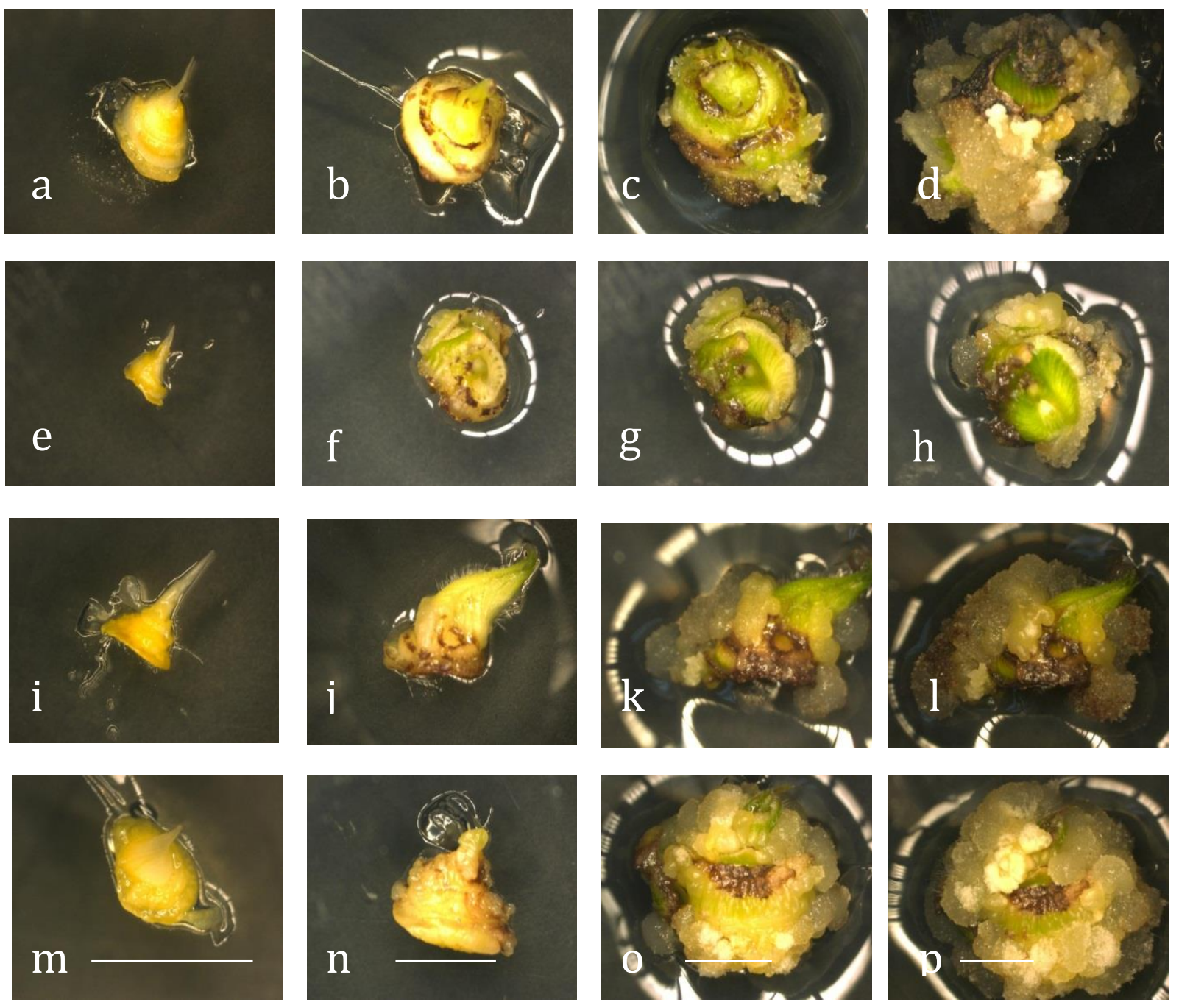

Figure 1. stages callus formation of 4 genotypes (a-d) dwarf, (e-h) hybrid, (i-l) merkeron and (m-n) wrukwona on callus induction medium MS medium containing $2 \mathrm{mgL}^{-1} 2,4-\mathrm{D}$ and $0.5 \mathrm{mgL}^{-1} \mathrm{BAP}$ in 30 days of culture.

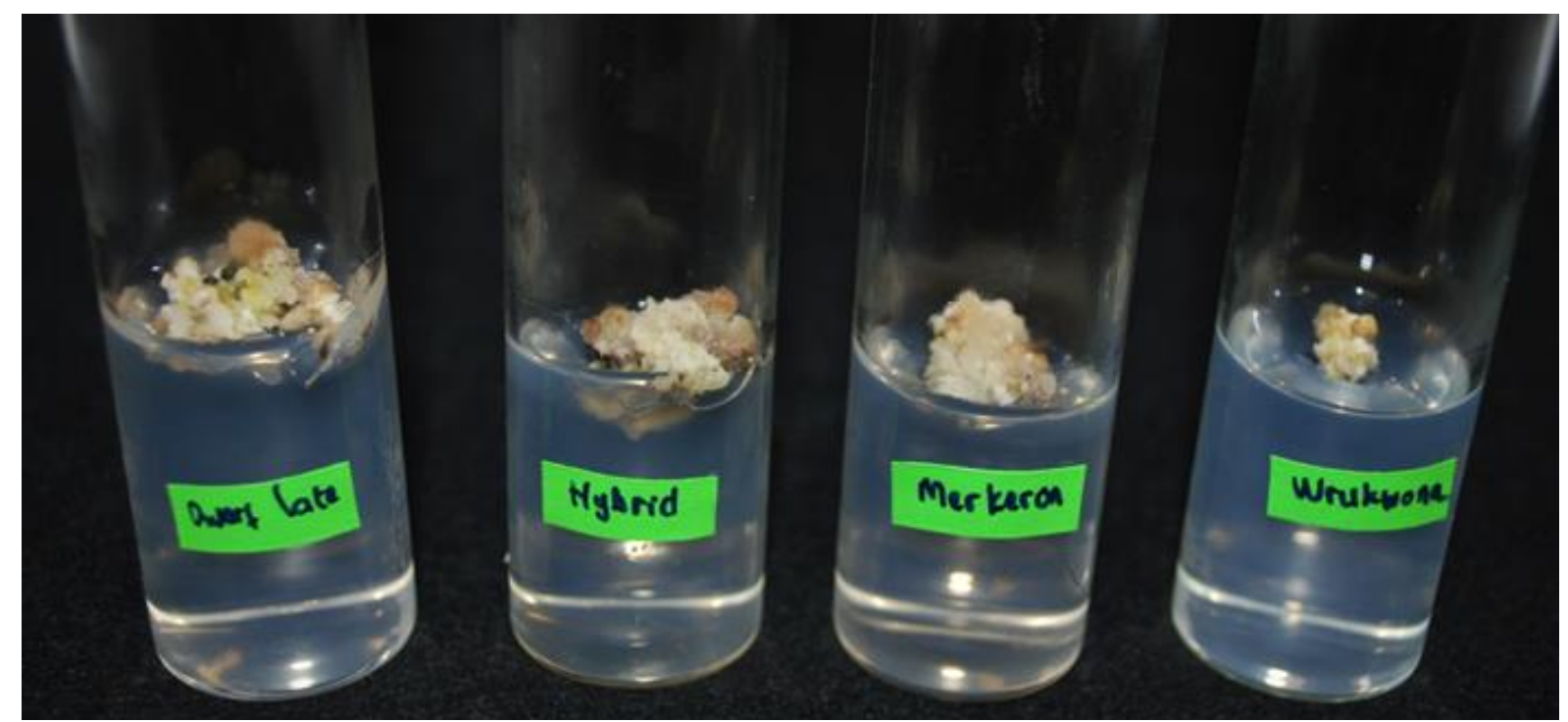

Figure 2. Callus formation of 4 genotypes (a-d) dwarf, (e-h) hybrid, (i-l) merkeron and (m-n) wrukwona on callus induction medium MS medium containing $2 \mathrm{mgL}^{-1} 2,4-\mathrm{D}$ and $0.5 \mathrm{mgL}^{-1}$ BAP 
Table 2. Proliferation rate of embryogenic calli derived from shoot apices in tiller of 4 genotypes napiergrass

\begin{tabular}{lcc}
\hline Genotype & D2B0.5 & D2B0.5CH \\
\hline Dwarf & ++ & +++ \\
Hybryd & + & + \\
Merkeron & ++ & ++ \\
Wrukwona & + & + \\
\hline
\end{tabular}

Proliferation rating: + poor, ++ moderate and +++ good.

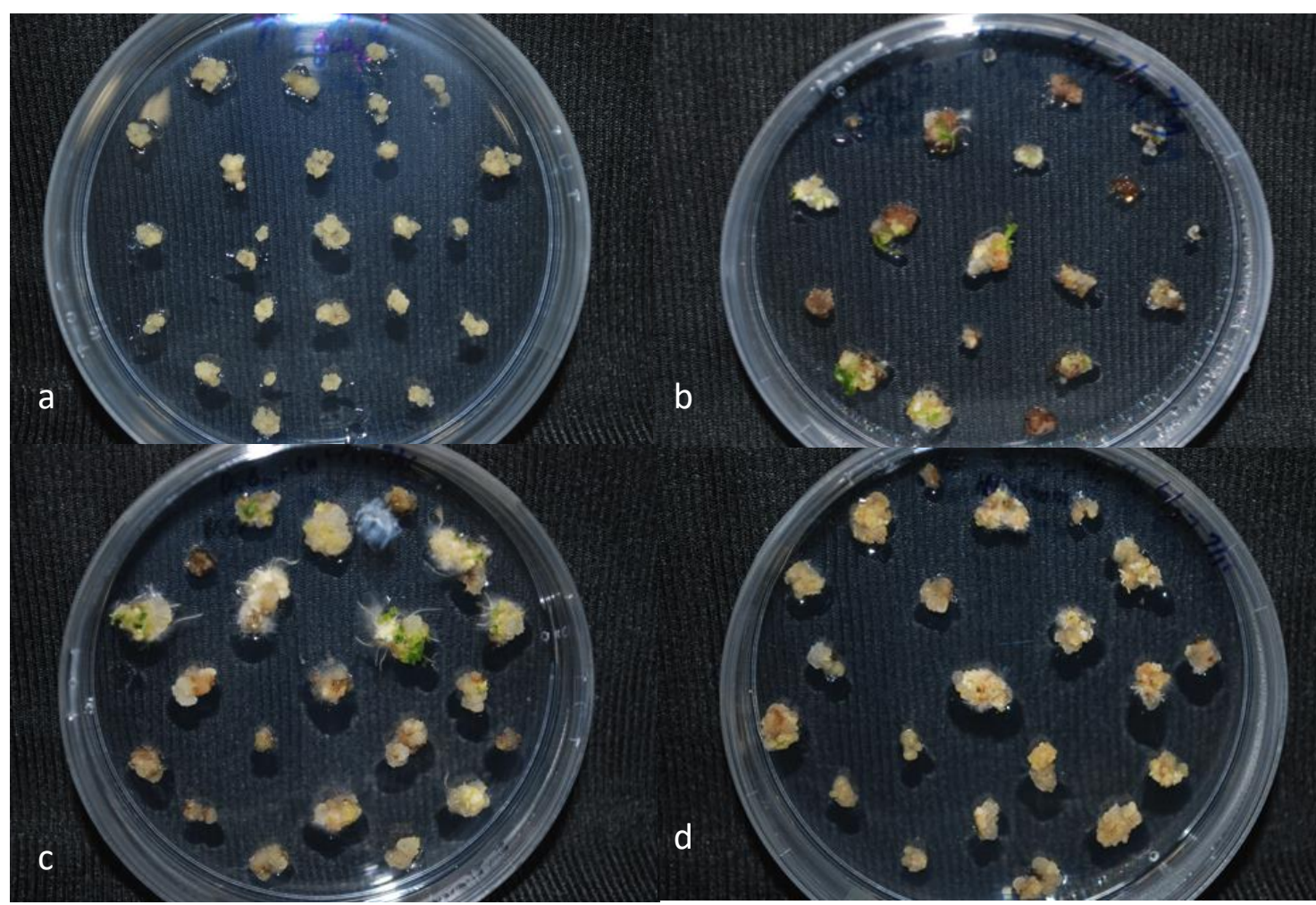

Figure 3. The proliferation of calli of 4 genotypes napiergrass a) dwarf, b) hybrid, c) merkeron and d) wrukwona on MS mediumcontaining $2 \mathrm{mgL} 2,4-\mathrm{D}$ and $0.5 \mathrm{mg}$ L BAP

However, in Merkeron culture callus formed shoot and root without proliferation.

In the culture of wrukwona variety, calli became brownish and some did not proliferate during two weeks. Some of them also sprouted soft callus on the surface. Shows in the Figure 3.Based on the observation, we can infer that the medium that the medium for proliferation is different from the medium for induction. Meanwhile, each genotype gives different response towards the medium and the ability to respond appears differently in each stage of culture. Some of calli were experimented to be transferres to the regeneration medium in the form of hormone-free MS solidmedium. On this medium, we germinated callus and the result is shown in Figure 4.
After callus grew in hormon free medium, it was transferred to half strenght MS medium. The result is shown in Figure 4. On the hormone-free medium, callus regeneration ability was obvious. Dwarf and Merkeron showed the best regeneration ability on hormon-free MS medium.

According to the research result above, It can be inferred that, phenotipically, the ability of embryogenic calli from different genotype resulted on different culture germination and rooting medium. Dwarf napiergrass had beter response toward in different media for the optimum culture condition of dwarf napiergrass. 


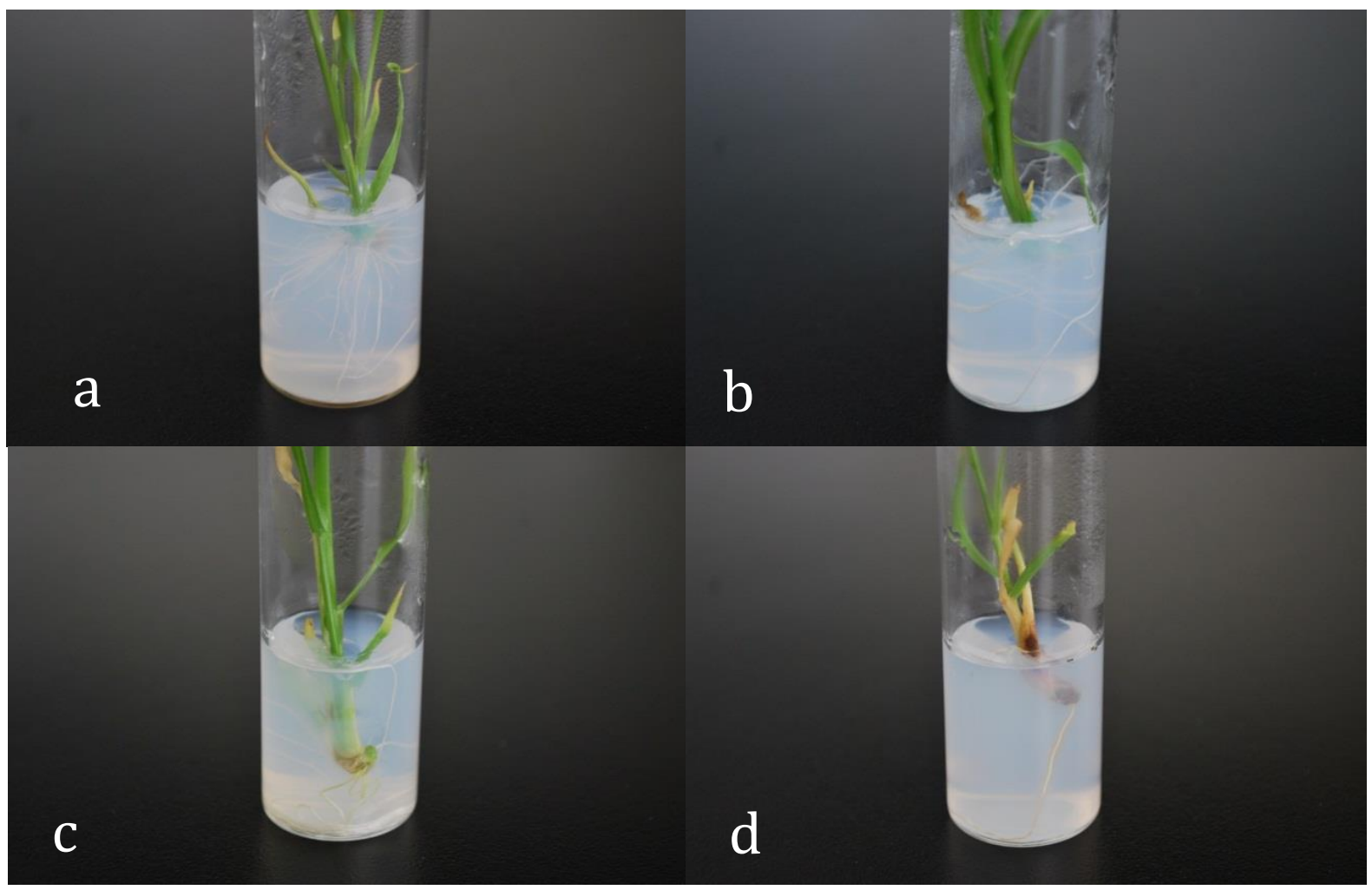

Figure 3. Embryogenic calli on free hormone MS media a) dwarf variety, b) Hybrid variety, c) Merkeron dan d) Wrukwona

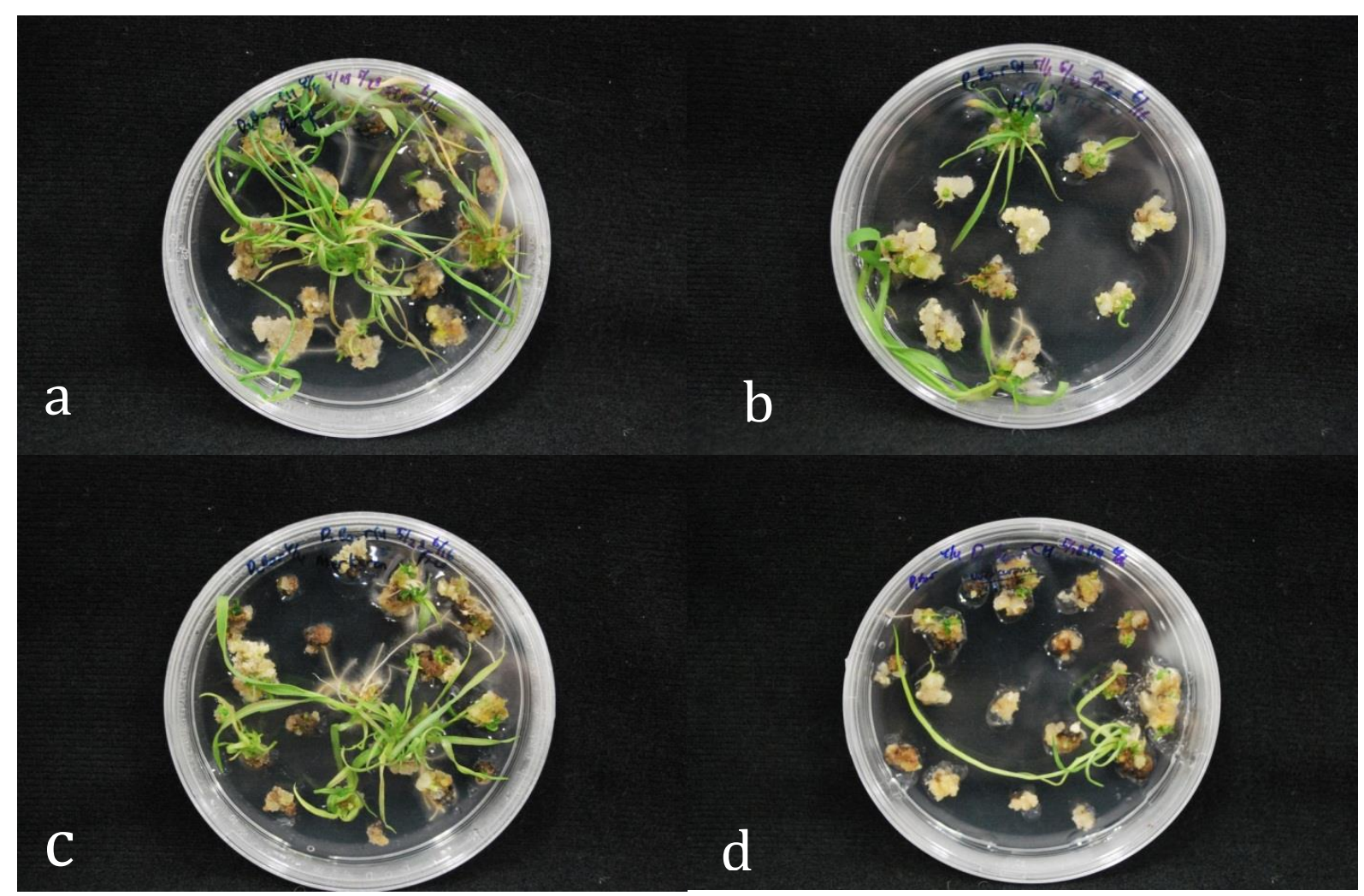

Figure 4. embryogenic calli on half strengh free hormone MS media a) dwarf variety, b) Hybrid variety, c) Merkeron dan d) Wrukwona. 
It is well known that the genotype, the interaction between genotype and medium (Khanna and Rainna, 1998), and also the interaction between genotype and explant have significant effect on callus induction. In this study, the effect of genotype and medium as significant. Maeda et al. (2002) reported that white and green patches are often seen on the surface stratum of callus with high regeneration ability. Moreover, in sorghum, Kaeppler and Pederson (1997) reported that the production of a high quality callus depends mainly on the genotype. Lee et al. (2002) found that the number, color, size, shape and appearance of the embryogenic calluses varied among the genotypes depending on the type of basal medium, indicating that induction of highquality napiergrass callus is influenced by genotype, medium, and the kind of explant as well as by their interactions.

In vitro Dwarf variety of Pennisetum purpureum provides a reliable sourse of basal segments for micropropagation (Figure 1) of dwarf Variety, as alternative explants. In another research Pinheiro et al., (2000) explained that basal segments of Brachiaria was good resourse for micropropagation. Previous assays with detachment of buds from the nodes of Brachiaria for invitro introduction were not efficient (Cabral et al., 2011).

Callus browning is one of the major problems in an in vitro culture. Abe and Futsuhara (1991) and Ogawa et al. (1999) argued that callus broning is genetically controlled, which correspond to the present study. A decrease in the rate of callus growth is occasionally related to the appearance of a brown colored area.

Although genotype contributed to the variation of traits observed, the contribution was not as large as expected in four genotype of napiergrass. This may be due to the similar genetic background of the materials used. A breeding programme in Tifton, Georgia, released a Pennisetum purpureum cultivar
Merkeron, derived from an intraspecific cross between a high yielding clone and a dwarf leafy clone, with improved yield and disease resistance (Burton, 1989). A selection from progeny of selfed 'Merkeron" resulted in Dwarf Tift N75/ Mott, a dwarf leafy type (Hanna and Monson, 1988).

In several monocotyle plants, the regeneration calluses derived from green vegetative tissue was difficult and few plantlets were obtained (Chaudhury and Qu, 2000). However maize (Zea mays) (Ahmadabadi et al., 2007) and barley (Li et al., 2009) have been efficiently regenerated from young leaf bases. Using in B. brizantha (Cabral et al., 2011) the same system used for maize, although calluses with embryo were observed, it was not possible to regenerate any plants in the trial condition. In this study we got several plantlets from Pennisetum purpureum four varieties.

It has been shown that reliable assesment on callus performance in example, good performance, with white/ cream appearance, healthy, actively growing that supposed to be embryogenic induced by some genotypes may lead to identify genotypes with high quality callus production. In this study dwarf napiergrass can produced high embryogenic calli and good growth for rooting and elongation of shoot. This selected genotypes were further examined for optimalisation condition for callus induction, and especially invitro plant regeneration since regeneration capacity is important for the success of genetic transformation experiments.

\section{Conclusions}

The conclusion of this study describes the advances made in napier grass tissue culture, one of members of Pennisetum purpureum. It highlights the achieved in establishing callus production method, and with 2,4 $\mathrm{D}$ and Cytokinin especially $2 \mathrm{mgL}^{-1}$ 2,4-D and $0.5 \mathrm{mgL}^{-1}$ BAP was more suitable to produce good quality 
callus, and reports the callus production system can be use as material in transformation system.

\section{Acknowledgement}

My grateful thanks are due Dr Yasuyuki Ishii, who gave me a permision to use shoot tillers of napiergrass, 4 genotypes. For kindly showing napiergrass meristems in the field also for founding some articles about napiergrass

\section{References}

Abe T and Y Futsuhara. 1991. Dialel analysis of callus growth and plant regeneration in rice seed callus. Japannese Journal of Genetica. 72:3-10.

Ahmadabadi M, Ruf S and Bock R. 2007. A leaf based regeneration and transformation and transformation system for maize (Zea mays L.). Transgenic Res 16: 437-448.

Akashi R and T Adachi. 1991. High frequency somatic embryo formation in culture of immature embryos of guineagrass, Panicum maximum JACQ. Japanese Journal of Breeding. 41: 85-93.

Akashi R and T Adachi. 1992. Somatic embryogenesis and plant regeneration from cultured immature inflorescences of apomictic dallisgrass (Paspalum dilatatum Poir). Plant Science. 82: 213-218.

Akashi R, A Hashimoto and T Adachi. 1993. Plant regeneration from seed-derived embryogenic callus and cel suspension cultures of bahiagrass (Paspalum notatum). Plant Science.90: 73-80.

Bovo OA and LA Mroginski LA. 1986. Tissue culture in Paspalum (gramineae): Plant regeneration from cultured inflorescences. Journal Plant Physiology. 124: 481-492.

Burris JN, Mann DGJ, Joyce BL, Stewart CN. 2009. An improved tissue culture system for embryogenesis callus production and plant regeneration in Swithcgrass (Panicum virgatum L.) Bioenergy research. 2:207-274.

Burton GW. 1989. Registration of Merekeron napiergrass. Crop Sci 29: 1327.

Cabral GB. Carneiro VTC. Lacerda AL. Valle SB. Martinelli AP and Dusi DMA. 2011. Somatic embryogenesis and organogenesia in apomictic and sexual Brachiaria brizantha. Plant Cell Tiss Organ Cult. 107: 217-282.

Chaudhury A, Qu R. 2000. Somatic embryogenesis and plant regeneration of turf type bermuda grass: Effect of 6-benzyladenine in callus induction medium. Plant Cell Tissue Organ. 60: 113-120.
Colomba EL, K Grunberg, S Griffa, A Ribotta, L Mroginski and E Siderbatt. 2006. The effect of genotype and culture medium on somatic embryogenesis and plant regeneration from mature embryos of fourteen apomictic cultivars of buffel grass (Cenchrus ciliaris L.). Grassland and Forage Science. 61:2006.2-8.

Cuomo GJ, DC Blouin and JF Beatty. 1996. Forage Potential of Dwarf napiergrass and a pearl millet $x$ napiergrass hybrid. Agronomical Journal. 88: 434-438.

Dai S, P Zheng, P Marme, S Zhang, W Tian, S Chen, RN Beachy and C Fauquet. 2001. Comparative analysis of transgenic rice plants obtained by agrobacterium-mediated ransformation and particle bombardment. Molecular Breeding. 7:25-33.

Gondo T, R Akashi and O Kawamura. 2002. Effect of BAP and cupric sulfate on embryogenic callus formation and plant regeneration in bahiagrass (Paspalum notatum Flugge). Grassland and Science. 50: 55-58. (In Japanese with English summary).

Gondo T, J Matsumoto, K Yamakawa, SI Tsuruta, M Ebina and $R$ Akashi. 2007. Somatic embryogenesis and multiple-shoot formation from seed-derived shoot apical meristems of rhodes grass (Chloris gayana Kunth). Grassland Science. 53:138-142.

Hanna WW and WG Monson. 1988. Registration of Dwarf N 75 napiergrass germplasm. Crop Science. 28: 270-271.

Haydu Z and IK Vasil. 1981. Somatic embryogenesis and plant regeneration from leaf tissues and anthers of Pennisetum purpureum Schum. Theor Appl Genet 59: 269-273.

Ishigaki G, T Gondo, K Suenaga and R Akashi. 2009. Multiple shoot formation, somatic embryogenesis and plant regeneration from seed-derived shoot apical meristems in ruzigrass (Brachiaria ruziziensis). Grassland Science. 55:4651.

Ishigaki G, T Gondo, M Ebina, K Suenaga and R Akashi. 2010. Estimation of genome size of Brachiaria species. Grassland Science: 56: 240242.

Kaeppler HF and JF Pederson. 1997. Evaluation of 41 elite and exotic inbred sorghum genotypes for high quality callus production. Plant Cell Tiss Org Cult 48: 71-75.

Kaeppler SM, HF Kaeppler and Y Rhee. 2000. Epigenetics aspects of somaclonal variation in plants. Plant Molecular Biology. 43: 179-188.

Khanna HK and SK Raina. 1998. Genotype x media culture interaction effects on regeneration response of three Indica rice cultivars. Plant Cell Tissue Organ Culture. 52:145-153. 
Lee $\mathrm{K}, \mathrm{H}$ Jeon and M Kim. 2002. Optimization of mature embryo-based in vitro culture system for high frequency somatic embryogenic callus induction and plant regeneration from Japonica rice cultivars. Plant Cell Tissue Organ Culture. 57:179-187.

Li HP, Huang T, Wang CX, and Liao YC. 2009. An efficient regeneration system of barley cultivars from leaf base segments. Biol Plant 54: 733-736.

Maeda E, T Sato and K Suzuki. 2002. Microtopography and shoot-bud formation of rice (Oryza sativa) callus. Plant Biotechnology. 19: 69-80.

Marousky FJ and SH West. 1990. Somatic embryogenesis and plant regeneration from cultured mature caryopsis of bahiagrass (Paspalum notatum flugge). Plant Cell Tissue Organ Culture. 20: 125-129.

Morrish F, V Vasil, and IK Vasil. 1987. Developmental morphogenesis and genetic manipulation in tissue and cell cultures of the gramineae. Advance Genetica. 24: 432-499.

Murashige $T$ and $F$ Skoog. 1962. A revised medium for rapid growth and bioassay with tabacco tissue culture. Physiology of the Plant 15: 473497.

Ochatt S, Durieu P, Jocas L, Pantecaille C. 2001. Protoplast cell and tissue culture for biotechnological breeding of grass pen (Lathyrus sativus L). Lathyrsm Newspaper 2: 35-38.

Ogawa T, H Fukuoka, H Yano and Y Ohkawa. 1999. Relationship between nitrite reductase activity and genotype-dependent callus growth in rice cell cultures. Plant Cell Reports 18: 576-581.

Pinheiro AA, Pozzobon MT, Valle CB, Penteado MIO and Carneiro VTC. 2000. Duplication of the chromosome number of diploid Brachiaria brizantha plants using Colchine. Plant Cell Rep 19: 274-278.

Prasertsongskun S. 2003. Plant regeneration from callus culture of Vetiver (Vetiver zizanioides Nash). Songklanakarin Journal Science Technology. 25: 637-642.

Vasil V dan IK Vasil. 1981. Somatic embryogenesis and plant regeneration from tissue cultures of Pennisetum americanum and Pennisetum americanum $\mathrm{x}$ Pennisetum purpureum hybrid. American Journal of Botany. 68: 864-872.

Vasil IK and DY Wang. 1982. Somatic embryogenesis and plant regeneration from inflorescence segments of Pennisetum purpureum Schum (napier or elephant grass). Plant Science Letter 25:147-154.

Visarada KBRS, M Sailaja and NP Sarma. 2002. Effect of callus induction media on morphology of embryogenic calli in rice genotypes. Biology Planta. 45: 495-502. 